\title{
LUT
}

University

\section{Exploring the Locus of Social Sustainability Implementation: A South Asian Perspective on Planning for Sustainable Development}

Awan Usama, Kraslawski Andrzej, Huiskonen Janne, Suleman Nazia

This is a Author's accepted manuscript (AAM) version of a publication

published by Springer, Cham

in Universities and Sustainable Communities: Meeting the Goals of the Agenda 2030

DOI: $10.1007 / 978-3-030-30306-8+5$

Copyright of the original publication: () Springer Nature Switzerland AG 2020

Please cite the publication as follows:

Awan, U., Kraslawski, A., Huiskonen, J., Suleman, N. (2020). Exploring the Locus of Social Sustainability Implementation: A South Asian Perspective on Planning for Sustainable Development. In: Leal Filho, W., Tortato, U., Frankenberger, F. (eds) Universities and Sustainable Communities: Meeting the Goals of the Agenda 2030. pp. 89-105. DOI: 10.1007/978-3-030-30306-8_5

This is a parallel published version of an original publication. This version can differ from the original published article. 


\title{
Exploring the locus of social sustainability implementation: A South Asian Perspective on Planning for Sustainable Development
}

\author{
*a Usama Awan, ${ }^{\mathrm{b}}$ Andrzej Kraslawski, ${ }^{\mathrm{c} J a n n e ~ H u i s k o n e n, ~}{ }^{\mathrm{d}}$ Nazia Suleman \\ a,b,c Industrial Engineering and Management, \\ Lappeenranta University of Technology Lappeenranta, Finland. \\ ${ }^{b}$ Department of Process and Environmental Engineering, Lodz University of Technology, Lodz, \\ Poland \\ ${ }^{\mathrm{d}}$ Department of Humanities, COMSATS University Islamabad, Vehari Campus, Pakistan.

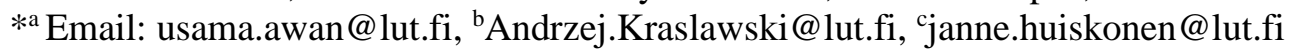

Keywords: Social sustainability Initiatives, Implementation, Supply chain management, Barriers, Multiple-criteria decision-making

\begin{abstract}
Social sustainability is one of the keys to sustainable development. The social sustainability agenda is not easy to be achieved without implementing pro-buyer and pro- institutional policies. A sustainable development not only calls for environmental and economic sustainability but also for social sustainability that is the basis of sustainable development. Moreover, commonplace unsustainable consumption practices increasingly manifest in manufacturing firms in developing countries, making sustainable development management failures highly visible and institutions relevant. We employee Multiple-criteria decisionmaking (MCDM) approach to identify the critical factors that hinder the implementation of social sustainability performance. There exists a scarcity of investigations on appropriate planning regarding a global partnership for achieving SDGs in the area of sustainable development. This paper provides an empirical analysis of the many practices that implementing sustainable development goals (SDGs), SDG 3, SDG5 and SDG17 pose, and contributes to sustainable development. To promote and meet the UNSD goals, it proposes adopting buyer requirements, improving institutional related policies are the most promising approaches to support and implementation of social sustainability. The aspects of social sustainability at manufacturing firms can be achieved primarily by buyer collaboration and better institutional policies. social sustainability has become a marketing tool and is becoming more important for all the companies, across all industries. We believe this paper is of interest to practitioners and academicians who deals with social sustainability initiatives at manufacturing firms.
\end{abstract}

\section{Introduction}

There is a growing trend towards developing a more sustainable way of managing social sustainability performance among the manufacturing firms. United Nations SDGs transformation calls for a broad partnership and requires a magnitude of the cooperation. The UNSDGs that set targets for 2030 seeks to promote sustainable development includes global goals, such as good health and well being, gender equality and partnership for the goals (United Nations, 2015). Social sustainability is one pillar that links to two other pillars of sustainable development (SD) that is, economic and environmental. To promote and meet the UNSD goals, it proposes adopting buyer involvement, skill, and development for meaningful 
collaboration. The sustainable development goals(SDGs) are a self-reliant dedication to accomplish, exactly what we began and also combat a few of the more demanding challenges experiencing the world today (ICSU, 2015).

There is a growing interest towards developing a more sustainable way of managing social sustainability performance among the manufacturing firms. Supply chain management practices have a detrimental impact on the environment, human health and economic sustainability. There is a growing recognition of social sustainability issues among buyers and suppliers. Buyer-supplier relationship has become a strategic means of achieving social performance for medium to large-sized firms. Relational governance among supply chain partners impact on adaptive capabilities for improvement in social sustainability(Awan, 2019). Many manufacturing companies are sourcing their suppliers from developing countries for low cost advantage(Mani, Agrawal, \& Sharma, 2016). The manufacturing firms are striving to satisfy sustainability requirements (SRs) in their products (Biju, Shalij, \& Prabhushankar, 2017). The results show that both product and process innovations decreased waste generation, raw materials, energy and water consumptions (Severo, Dorion, \& Guimarães, 2017). Therefore, it is important for manufacturing industries to deal with various barriers associated with their customers, employees, and management, to achieve social sustainability performance in a supply chain scenario. It is also a timely study, some recent accidents in Pakistan, Ali Enterpriser factory, supplier for German-based low-cost retailer KiK collapsed, killing 254workers. Thus, risk base production facilities may have an impact on firm sustainability and it may have some adverse effect on society. In order to achieve sustainability targets, manufacturing firms need to identify challenging initiatives and implementation of environmentally friendly practices into their supply chain (Mani, Gunasekaran, Papadopoulos, Hazen, \& Dubey, 2016).

There is an inappropriate understanding of social sustainability issues leading to ineffective solutions; the consequences of these failures are serious for worker occupational health and safety. In order to sustain employee occupational health and safety issues in the long run, the manufacturing firm needs to make effectively incorporate sustainability issues into their supply chain management (Tseng \& Hung, 2014). Since the last few years, interest in social sustainability issues in the supply chain has attracted attention from the manufacturing firms, aspire to engage in socially sustainable practices (Mette Andersen \& Skjoett-Larsen, 2009; Venkatesh Mani et al., 2016). Social sustainability is an emerging research area which encompasses human health, safety, social capital, social equity and comfort and required researcher attention(Popovic and Kraslawski, 2015). The social sustainability performance perspective points out the potential importance of the buyersupplier commitment to supply chain relationship(Awan, 2019). Still, the challenge in the developing countries is to categorize a good number of persistent barriers impeding the implementation of social sustainability practices(Mani et al., 2016). The ever-increasing awareness on social issues in the supplier-manufacturing firm in developing countries means that there is a need to understand barriers that hinder for the implementation of social practices.

However, there are several practical challenges for implementations. There exists a scarcity of investigations on appropriate planning regarding a global partnership for achieving SDGs in the area of sustainable development. This paper provides an empirical analysis of the many practices that implementing sustainable development goals (SDGs), SDG 3, SDG5 and SDG17 pose, and contributes to sustainable development. To address this research gap, we build on the analytical hierarchy process (AHP), such that we model the factors that are most challenging in the implementation of social sustainability practices. The objective of the present study is (1) to prioritize barriers hindering the effective 
implementation of social sustainability practices. This study attempts to answer the research questions, what are the existing barriers to implement social sustainability practices in manufacturing firms in emerging country perspective? In answering these questions, we particularly contribute to the field by identifying how social sustainability initiatives can be promoted in the manufacturing firms. This study proposes a structural model for evaluating the barriers associated with the implementation of social sustainability initiatives in a supply chain. The proposed model can use as the roadmap to their implementation of social sustainability initiatives. The findings of this study offer contribution to social sustainability. This paper contributes to the increasing body of research on how different barriers influences to implement social sustainability practices by (1) taking a perspective on the developing country perspective, and (2) our findings add to understanding to implement social sustainability practices that may potentially help the firm evolve as socially responsible over the time.

\section{Literature Review Social Sustainability}

Social sustainability underpins by a wide range of activities and practices related to social issues. The primary concern with devising such ways and practices to concern with developing process and products and incorporate efficient ways to incorporate broader employee and community perspective. The concept of sustainability appeared in (Elkington $\&$ Burke, 1987). The concept of Social sustainability first appeared in agenda 21 in Rio conference on social aspects. Since then social sustainability in the supply chain has emerged a study area and brought the concept to global prominence. It is regarded as integral to sustainability in order to achieve sustainable development in both developing and industrialized countries(Hutchins \& Sutherland, 2008). Hutchins \& Sutherland (2008) argued that a firm supply chain that is socially sustainable, must establish policy and laws within firms and with its employees, devise policies about employee health and safety, working conditions, wages, child labour, labour hours, betterment for local community and society. Social sustainability practices are therefore characterized by health and safety, equity, wages, discrimination, equal opportunity, employability, safety and quality of life both employee and society (Mette Andersen \& Skjoett-Larsen, 2009; Klassen \& Vereecke, 2012a; Husgafvel, Pajunen, Virtanen, Paavola, Päällysaho, Inkinen, Heiskanen, Dahl, \& Ekroos, 2015). Social sustainability is a system of coordinated social interaction practices for the management of the social impact on people and society with the key internal and external stakeholders. This all happens for creating, developing and delivering the best social and ethical code of conduct (Awan; Andrzej Kraslawski; Janne Huiskonen, 2018)

Other studies (Hutchins \& Sutherland, 2008; V Mani, Agrawal, \& Sharma, 2015) discussed different dimensions and came to conclude that social sustainability measures are important for reaching sustainable development goals. Furthermore, social sustainability is a key factor for the development of industry, it covers broad employee and societal issues and emphasizes the expectations and needs that the local community has for wellbeing. Implementations of social sustainability practices are considered to be one of the most challenging and therefore it needs to employ procedural and contextual social sustainability (Suopajärvi, Poelzer, Ejdemo, Klyuchnikova, Korchak, \& Nygaard, 2016). In the current global environment, buyer involvement can contribute to the improvement of occupational and health practices. The social sustainability aim is, to have value for the survival of current business system (customers, partners, and society) and its growth for the future generation in an equitable and prudent manner(Usama away; Andrzej Kraslawski; Janne Huiskonen, 2018). 


\section{Identification of Barriers}

Technical barriers are critical to achieving the sustainability objectives. Social sustainability issues in the supply chain are still in its developing state with many challenges and issues. Lack of awareness and knowledge among the employees about social practices in the supply chain is a major barrier for manufacturing companies(Schaltegger, 2011).In many developing countries non-availability trained human resource and resistance to adopting new practices may hinder the sustainable growth (Merli, Preziosi, \& Massa, 2015). The major injuries and accidents at the workplace result from faulty machinery, equipment, or facilities.

Effectiveness and efficiency of facilities, equipment, and machines contribute to the reduction of accidents and injuries at the workplace (Amponsah-Tawiah, Ntow, \& Mensah, 2015). Achieving desired results in the implementation of social issues lying with the availability of the resources and it is a barrier that hinders implementation efforts. Technical barriers might include a focus on both the knowledge of equipment and machines contributes to improving safety at the workplace. Lack of involvement of operational staff into decision making can act as a challenging barrier for re-design the whole or part of the system. It is the obvious successful implementation of any quality management program is dependent on managerial decision making (Baumgartner, 2009; Ehrgott, Reimann, Kaufmann, \& Carter, 2011). This highlights the need for more flexible employee work behaviour and more resilient approach towards practices and policies including repeated and improvable process and ability to retransformation of resources is a key towards attaining sustainable performance. Shoetown achieved world-class best practice in sustainable management The management at Shoetown utilise a skillful mix of eastern and western business theories embedded in the Chinese business context(Huang, Moore, \& McCarthy, 2014).

According to Mamic (2005), lack of participation and promotion from government and social communities on social issues affect the implementation of social initiative programs. Moreover, challenges arise due to the lack of action plans and strategies and uncertainty from institutions (Dube et al., 2016). The researcher has suggested that a strategic tie-up between supportive policies and guidance from institutional actors can have a positive influence on social initiative actions (Lim and Phillips 2008). It is argued that in order to the successful implementation of these issues, firms need to understand the priority barriers that hinders in the effective implementation of strategies and actions plans form institutions.

The mutual understanding of buyer and supplier is crucial to enhance the competence of socially responsibility issues in the supply chain. Prior researchers have reported that a lack of lack of shared understanding and exchange of information on best practices is an important barrier (Gualandris, Klassen, Vachon, \& Kalchschmidt, 2015). There is also resistance to the implementation and understanding how to improve the productions and process system and find a right balance between prod, However, interaction frequency, in particular, might not always be beneficial.uction and safety within operational level influence achieving sustainable performance (Schaarschmidt \& Hoeber, 2017).

\section{Solution Methodology}

AHP has been recognized as an important tool in sustainability decision making for identifying and competing decisions objective. The use of AHP in the decision-making process can be found in various research studies and have previously been applied in sustainability decision making. AHP has been used for complex decision making and it organizes factors into categories and sub-categories (Saaty, 2008). Analytical Hierarchy Process (AHP) has been recognized and applied in a wide of variety of practical decisionmaking. Based on the literature review, AHP has been used in evaluation, ranking and 
prediction of decision making (Luthra, Mangla, Xu, \& Diabat, 2015). AHP was developed and was originated from the Wharton School of Business by (Saaty, 1987). AHP is an appropriate decision-making tool for decomposing the relationship into objective, categories and sub-categories and alternatives. The use of AHP in the present study allows for developing a hierarchy of goals and their criteria, sub-criteria, and evaluation of alternatives. AHP not only help to assess the determining the linkages between the selected barriers and corresponding to evaluate alternatives but also helps to formulate policies and strategies to manage social sustainability initiatives. AHP has been widely used in different research fields due to its usefulness in decision-making process, such as supply chain logistics, healthcare, engineering, new product development and information technology management and many others (Singh 2013; Luthra et al., 2011; Luthra et al., 2015) In this study, a computational method was used to determine the priority factor in decision making. This study uses the AHP to evaluate and determine the barriers to the social sustainability decision making.

To begin with, the sub-categories of the hierarchical model is shown in fig.1.

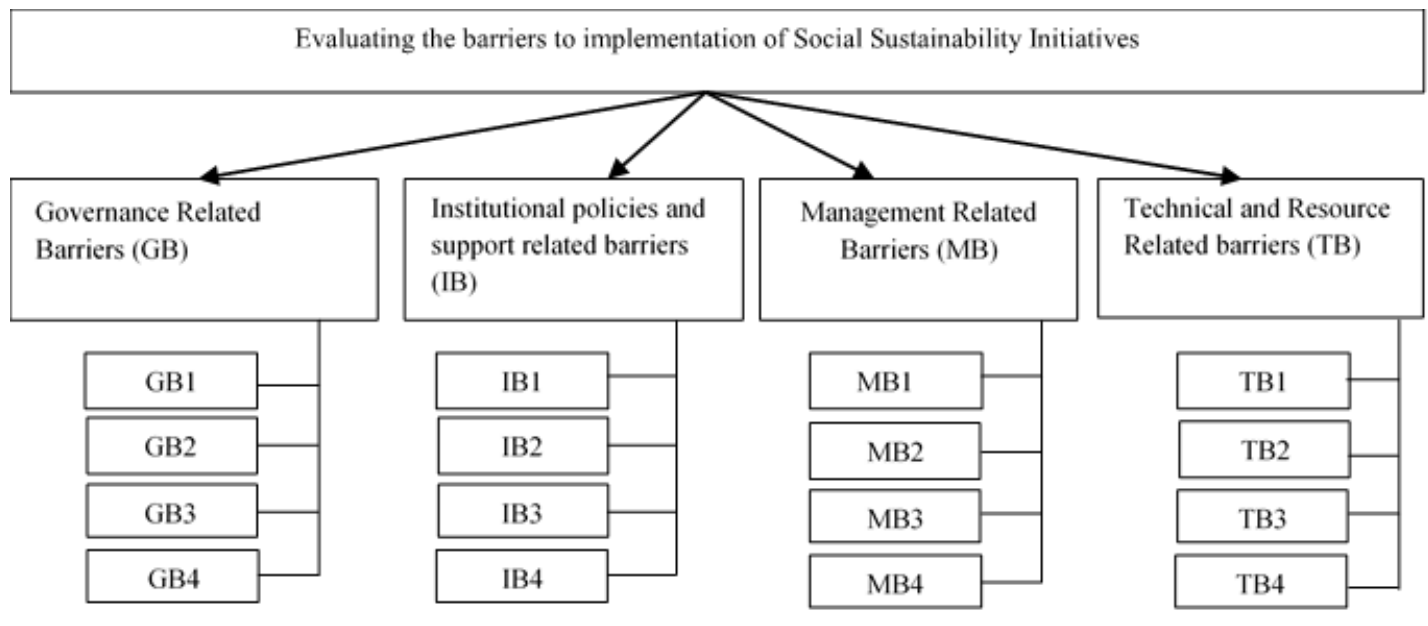

Fig. 1. Hierarchical decision model

\section{Research Methods}

In order to identify the barriers to the implementation of social sustainability by manufacturing firms, a literature review was conducted. Further, a list of selected key barriers was sent to experts to select the likely key barriers in the Pakistan context. Base on their recommendation, additional barriers items were categories. The list of barriers was also evaluated by experts to ensure to have their insight, belongs to diverse titles from the manufacturing industries, representing, and sports goods and Leather wares manufacturing firms. After consulting with the experts, a questionnaire was constructed to reflect the key barriers for social initiatives are shown in (Table.1). The finalized 16 social initiative barriers were analyzed using AHP. Significance consistency ratio value set at $<10 \%$ for all compare wise comparison matrices. The identified barriers were further grouped into four major categories (see table.1). The final barriers were then categorized into 4 dimensions base on their nature, governance-related Barriers (GB), Institutional policies and support related barriers (IB), Technical and Resource-Related barriers (TB), Management Related Barriers (MB).

Pakistan manufacturing goods industry is vibrant and considered for this study. The sports and surgical manufacturing industries are situated in Sialkot North Pakistan; these 
firms internationally well know which act as a major source of revenue and backbone of Pakistan economy. The identified barriers were then sent to select 87 manufacturing firms. The respondents were also requested to compare carefully the categories and sub-categories of each hierarchy level by assigning a relative measure in pairwise comparison with respect to the nine-point scale of intensity (See Table.2). With the use of this table, the comparison matrix for specific categories and relative weights are calculated by assigning numerical values in (Table.3. Random Index (RI) consistency index values). The duration of the survey was six weeks, at the end of this period, 34 responses were received from targeted firms. The incomplete questionnaires were not considered, and 6 responses were abandoned.

The result was satisfactory as the response rate was $39.08 \%$ and acceptable for the analysis (Malhotra \& Grover, 1998). The respondents were also asked to compare carefully the categories and sub-categories of each hierarchy level by assigning a relative measure in pairwise comparison with respect to the nine-point scale of intensity (See Table.2). With the use of this table, the comparison matrix for specific categories and relative weights are calculated by assigning numerical values in (Table.3. Random Index (RI) consistency index values).

Table.1 Identification of barriers to social sustainability initiatives

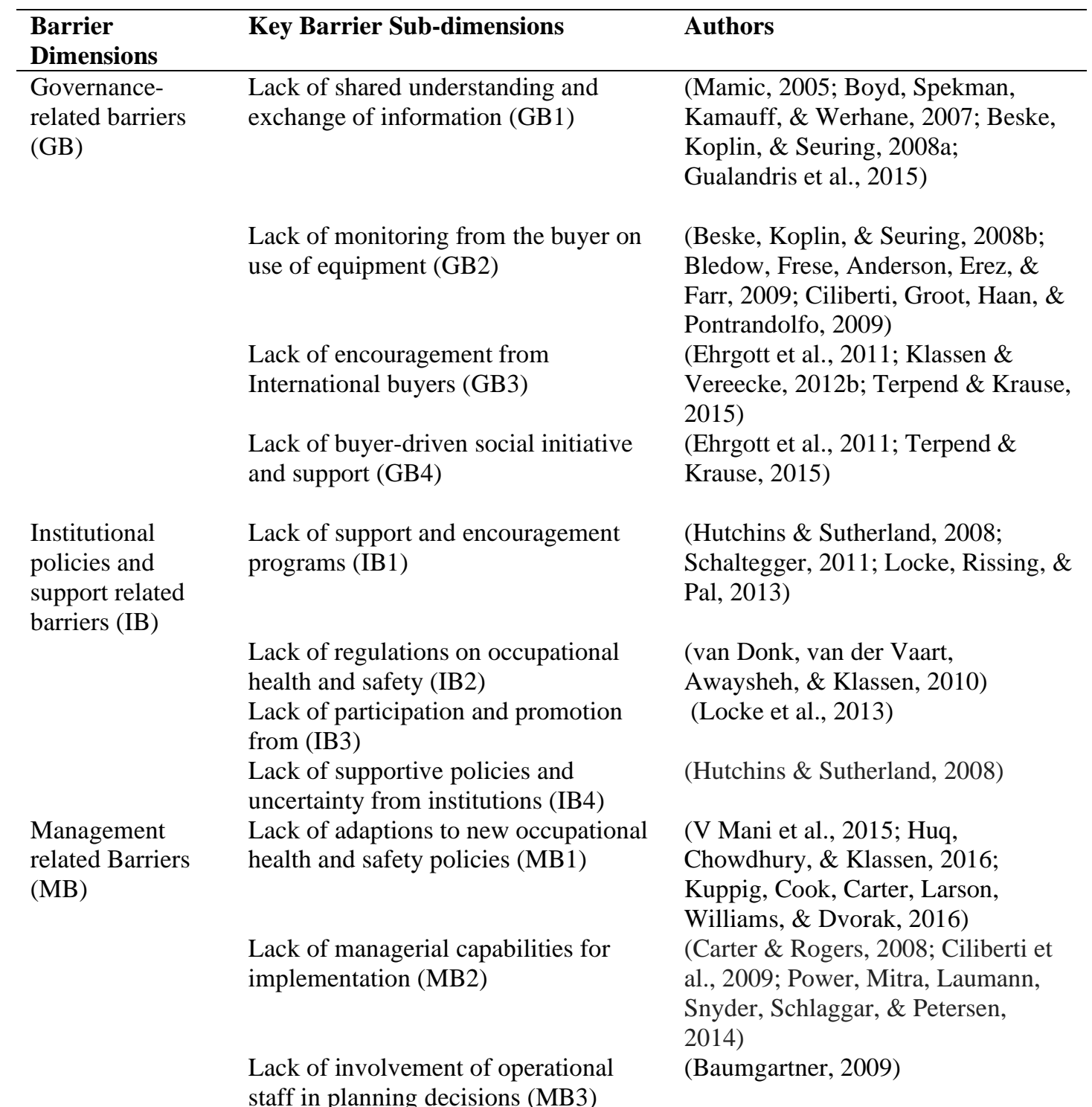

staff in planning decisions (MB3) 
Lack of flexibility and resilience skills (MB4)

Technical and resource-related barriers (TB)

Lack of knowledge of resource management (TB1)
Lack of acceptance to adopt new practices (TB2)

Lack of use of protecting equipment and practices (TB3)

Lack of technical resources for maintenance equipment (TB4)
(Bhamra, Dani, \& Burnard, 2011)

(Amponsah-Tawiah et al., 2015;

Sartor, Orzes, Di Mauro,

Ebrahimpour, \& Nassimbeni, 2016)

(Merli et al., 2015; Sartor et al., 2016)

(van Donk et al., 2010; Amponsah-

Tawiah et al., 2015)

(Kuppig et al., 2016)

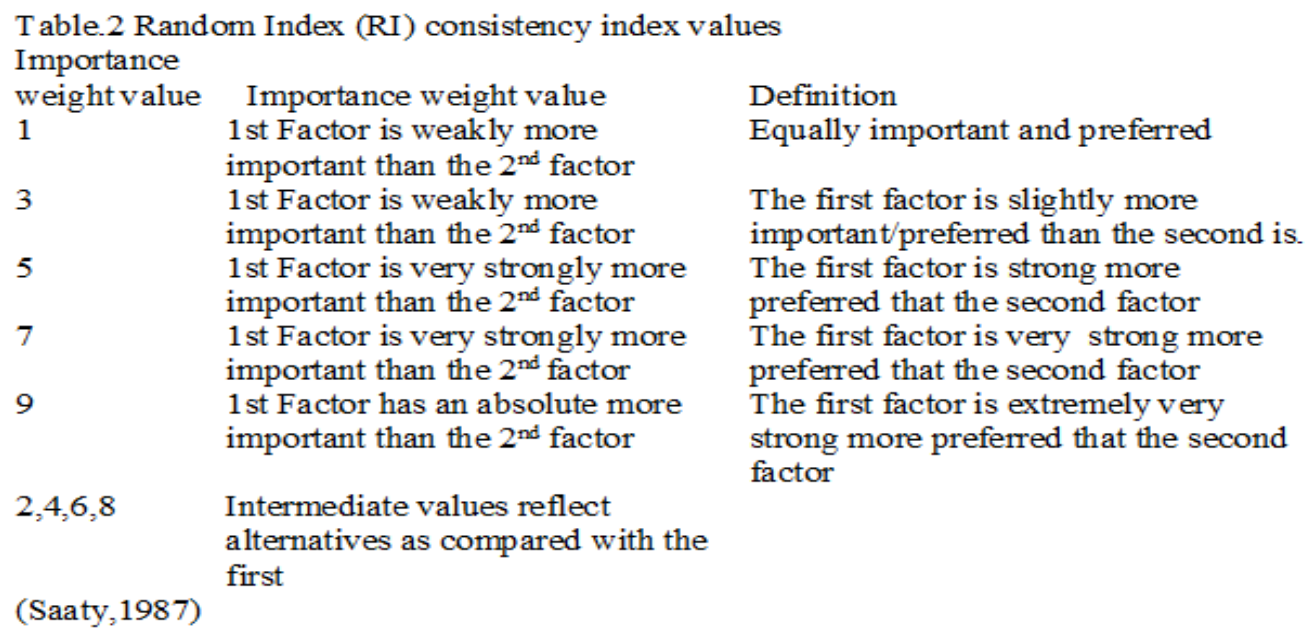

\section{Results and Analysis}

The results of the pairwise comparison matrix is provided in Table. 4 of the four categories to the implementation of social sustainability barriers. From the computational performed, the results of the pairwise comparison of sub-categories are illustrated (Table.5-8). In the present study, the results of AHP modeling reveals that governance Related Barriers (GB) is a leading barrier followed by Technical and Resource-Related barriers (TB). Management Related Barriers (MB) and Institutional policies and support related barriers (IB) occupy third and fourth most important barriers, which is not an as much serious concern.

Table.3 Random Index (RI) consistency index values

\begin{tabular}{lcccccccccc}
\hline Size of matrix & 1 & 2 & 3 & 4 & 5 & 6 & 7 & 8 & 9 & 10 \\
\hline $\begin{array}{l}\text { Random } \\
\begin{array}{l}\text { consistency } \\
\text { index (RCI) }\end{array}\end{array}$ & 0 & 0 & 0.58 & 0.90 & 1.12 & 1.24 & 1.32 & 1.41 & 1.45 & 1.51 \\
\hline
\end{tabular}

Table.4 pairwise comparison matrix of the four categories

\begin{tabular}{lllllll}
\hline Barriers Categories & GB & IB & MB & TB & Weights & Ranking \\
\hline $\begin{array}{l}\text { Governance Related } \\
\text { Barriers (GB) }\end{array}$ & 1 & 7 & 5 & 3 & 0.563179 & 1
\end{tabular}




\begin{tabular}{|c|c|c|c|c|c|}
\hline $\begin{array}{l}\text { Institutional policies and } \\
\text { support related barriers (IB) }\end{array}$ & $1 / 7$ & 1 & $1 / 4$ & $1 / 5$ & 0.054227 \\
\hline $\begin{array}{l}\text { Management Related } \\
\text { Barriers (MB) }\end{array}$ & $1 / 5$ & 4 & 1 & $1 / 2$ & 0.145552 \\
\hline $\begin{array}{l}\text { Technical and Resource } \\
\text { Related barriers (TB) }\end{array}$ & $1 / 3$ & 5 & 2 & 1 & 0.237043 \\
\hline Sum & 1.6762 & 17.0000 & 8.2500 & 4.7000 & \\
\hline
\end{tabular}

Table.5 Pairwise comparison matrix for buyer governance related barriers (GB)

\begin{tabular}{lllllll}
\hline $\begin{array}{l}\text { Barriers } \\
\text { Categories }\end{array}$ & BB1 & BB2 & BB3 & BB4 & Weigths & Ranking \\
\hline GB1 & 1 & 6 & 4 & 2 & 0.506046 & 1 \\
GB2 & $1 / 6$ & 1 & $1 / 2$ & $1 / 5$ & 0.069776 & 4 \\
GB3 & $1 / 4$ & 2 & 1 & $1 / 3$ & 0.135440 & 3 \\
GB4 & $1 / 2$ & 5 & 2 & 1 & 0.288737 & 2 \\
Sum & 1.9167 & 14.0000 & 8.5000 & 3.5333 & & \\
\hline
\end{tabular}

Note: $\lambda_{\max }=4.118243$ for $n=4, C I=0.039414, C R=0.043793$

Table.6 Pairwise comparison matrix for technical and resource-related barriers (TB)

\begin{tabular}{lllllll}
\hline $\begin{array}{l}\text { Barriers } \\
\text { Categories }\end{array}$ & TB1 & TB2 & TB3 & TB4 & Weights & Ranking \\
\hline TB1 & 1 & $1 / 2$ & $1 / 3$ & 3 & 0.162301 & 3 \\
TB2 & 2 & 1 & $1 / 2$ & 5 & 0.287893 & 2 \\
TB3 & 3 & 2 & 1 & 7 & 0.489437 & 1 \\
TB4 & $1 / 3$ & $1 / 5$ & $1 / 7$ & 1 & 0.060369 & 4 \\
Sum & 6.3333 & 3.7000 & 1.9762 & 16.0000 & & \\
\hline
\end{tabular}

Note: $\lambda_{\max }=4.0262331$ for $n=4, C I=0.008744, C R=0.009716$

Table.7 Pairwise comparison matrix for management related barriers (MB)

\begin{tabular}{lllllll}
\hline $\begin{array}{l}\text { Barriers } \\
\text { Categories }\end{array}$ & MB1 & MB2 & MB3 & MB4 & Weights & Ranking \\
\hline MB1 & 1 & $1 / 4$ & 6 & 3 & 0.252320 & 2 \\
MB2 & 4 & 1 & 8 & 5 & 0.589774 & 1 \\
MB3 & $1 / 6$ & $1 / 8$ & 1 & $1 / 2$ & 0.055281 & 4 \\
MB4 & $1 / 3$ & $1 / 5$ & 2 & 1 & 0.102625 & 3 \\
SUM & & & & & & \\
\hline
\end{tabular}

Note: $\lambda \max =4.231368$ for $n=4, C I: 0.077122, C R: 0.0856918$

After the pairwise comparison, local weights of a total of 16 barriers (from Table. 5-9) with global weights with respect to the highest relative importance at the hierarchical level are presented in Table.9. Lack of shared understanding and exchange of information (0.284994), with regard to global weight results, is the most prioritized barrier among the 16 barriers to the implementation of social sustainability practices. The second and third most important barrier is "Lack of buyer-driven social initiative and support" $(0.162611)$. This means the 
absence of this barrier firm can make more progress towards better implementation of social practices.

\begin{tabular}{|c|c|c|c|c|c|c|c|}
\hline Barriers & *RW & $*_{\mathrm{R}}$ & Barriers Sub-Categories & $* \mathrm{RW}$ & $* \mathrm{R}$ & GW & $* \mathrm{R}$ \\
\hline & & & $\begin{array}{l}\text { Lack of shared } \\
\text { understanding and }\end{array}$ & 0.506046 & 1 & 0.284994 & 1 \\
\hline \multirow{7}{*}{$\begin{array}{c}\text { Governanc } \\
\text { e-related } \\
\text { barriers } \\
\text { (GB) }\end{array}$} & & & $\begin{array}{l}\text { exchange of in formation } \\
\text { (GB 1) }\end{array}$ & & & & \\
\hline & & 1 & $\begin{array}{l}\text { Lack of monitoring from } \\
\text { buyers on use of } \\
\text { equipment (GB2) }\end{array}$ & 0.069776 & 4 & 0.039296 & 7 \\
\hline & 0.563 & & Lack of encouragement & 0.135440 & 3 & 0.076277 & 5 \\
\hline & 179 & & $\begin{array}{l}\text { from International } \\
\text { buyers(GB3) }\end{array}$ & & & & \\
\hline & & & $\begin{array}{l}\text { Lack of buyer-driven } \\
\text { social initiative and } \\
\text { support (GB4) }\end{array}$ & 0.288737 & 2 & 0.162611 & 2 \\
\hline & & & $\begin{array}{l}\text { Lack of support and } \\
\text { encouragement programs }\end{array}$ & 0.486906 & 1 & 0.026403 & 10 \\
\hline & & & (2) & & & & \\
\hline \multirow{4}{*}{$\begin{array}{l}\text { Institutiona } \\
1 \text { policies } \\
\text { and } \\
\text { support } \\
\text { related } \\
\text { barriers } \\
\text { (IB) }\end{array}$} & $\begin{array}{c}0.054 \\
227\end{array}$ & 4 & $\begin{array}{l}\text { Lack of regulations on } \\
\text { occupational health and } \\
\text { safety (IB2) }\end{array}$ & 0.059091 & 4 & 0.003204 & 16 \\
\hline & & & $\begin{array}{l}\text { Lack of participation and } \\
\text { promotion from (IB3) }\end{array}$ & 0.148996 & 3 & 0.008079 & 14 \\
\hline & & & $\begin{array}{l}\text { Lack of supportive } \\
\text { policies and uncertainty } \\
\text { from institutions (IB } 4 \text { ) }\end{array}$ & 0.305006 & 2 & 0.016539 & 11 \\
\hline & 0.145 & & $\begin{array}{l}\text { Lack of adaptions to } \\
\text { occupational health and } \\
\text { safety policies. MB1) }\end{array}$ & 0.252320 & 2 & 0.036726 & 9 \\
\hline \multirow{4}{*}{$\begin{array}{c}\text { Manageme } \\
\text { nt related } \\
\text { barriers } \\
(\mathrm{MB})\end{array}$} & 552 & 3 & $\begin{array}{l}\text { lack of managerial } \\
\text { capabilities for } \\
\text { implementation (MB2) }\end{array}$ & 0.589774 & 1 & 0.085843 & 4 \\
\hline & & & $\begin{array}{l}\text { Lack of involvement of } \\
\text { operational staff in } \\
\text { planning decisions(MB3) }\end{array}$ & 0.055281 & 4 & 0.008046 & 15 \\
\hline & & & $\begin{array}{l}\text { Lack of flexibility and } \\
\text { resilience skills(MB4) }\end{array}$ & 0.102625 & 3 & 0.014937 & 12 \\
\hline & & 2 & $\begin{array}{l}\text { Lack of knowledge on } \\
\text { resource management }\end{array}$ & 0.162301 & 3 & 0.038472 & 8 \\
\hline \multirow{4}{*}{$\begin{array}{l}\text { Technical } \\
\text { and } \\
\text { resource- } \\
\text { related } \\
\text { barriers } \\
\text { (TB) }\end{array}$} & 0.237 & & (TB1) & & & & \\
\hline & 043 & & $\begin{array}{l}\text { Lack of acceptance to } \\
\text { adopt new practices } \\
\text { (TB2) }\end{array}$ & 0287893 & 2 & 0.068243 & 6 \\
\hline & & & $\begin{array}{l}\text { Lack of use of protecting } \\
\text { equipment and practices } \\
\text { (TB3) }\end{array}$ & 0.489437 & 1 & 0.116018 & 3 \\
\hline & & & $\begin{array}{l}\text { Lack of technical } \\
\text { resources for maintenance } \\
\text { equipment (TB4) }\end{array}$ & 0.060369 & 4 & 0.014310 & 13 \\
\hline
\end{tabular}

Relative weights $=* \mathrm{RW}$; Ranking $=* \mathrm{R}$; Global Weigths $=\mathrm{GW}$

This shows that firm is giving leas importance to "Institutional policies and support" and in global weigh category it holds the lowest ranked position 16, 14, 10 and 11 respectively. Due to lack of buyer-driven social initiatives and support firm is not motivated towards implementation of social practices. 
The Third barrier "Lack of use of protecting equipment and practices" $(0.116018)$ followed by lack of managerial capabilities for implementation (0.085843), "Lack of encouragement from International buyers" (0.076277) and "Lack of acceptance to adopt new practices" (0.068243). These barriers are important and necessary to overcome and hinder the successful implementation of the case firm. The understanding of these priority barriers will help the managers to understand them, so they can implement social sustainability initiatives program in their firm. This shows that lack of management capabilities of the firm is a most important barrier for the firm and management and managers of the firm are not able to provide a great deal of the support in the implementation of social initiatives in the supply chain. It requires the firm to make essential changes and adopt new practices. This shows that building capabilities are a key strategy for transforming social sustainable behaviour across the supply chain (Ciliberti et al., 2009). For example, if a firm is lack of management capabilities, then it will be a permanent failure on which no social initiative can be implemented.

\section{Conclusions}

The UNSDGs that set targets for 2030 seeks to promote sustainable development includes global goals, such as good health and well being, gender equality and partnership for sustainable development. The objective of the study was to prioritize the most significant barriers that hinder the successful implementation of social sustainability practices in the manufacturing firms. We identified two important factors. First, we found that governance related barriers effect on sustainable performance, as it values activities related to exchange of information, monitoring suppliers, support from buyers and buyer-driven knowledge driven practices. Hence, support from the buyer can be necessary to ensure exposure to diverse practices on social initiatives and can help of integrating these inputs an adjusting to new market demands. Second, Institution policies and support is the least important barrier, implies that it requires focused attention from government bodies, policymakers need to prioritize the elimination of these barriers to promote social sustainability. There are various barriers encountered in implementing social sustainability practices for the manufacturing firms in Pakistan. The top three critical barriers encountered in practice are highlighted as 'Lack of shared understanding and exchange of information', 'Lack of buyer-driven social initiative and support', 'Lack of use of protecting equipment and practices'. The multi-criteria decision-making process in the paper has evidenced this. In this context, there is an urgent need for proactive support from the buyers. On the other side, institution policies and support is the least important barrier, implies that it require focused attention from government bodies, policymakers need to prioritize the elimination of these barriers to promote social sustainability. A path to enhanced social sustainability will be built by expanding the scope of buyer-supplier relationship and institutional environment. A socially sustainable future will emerge if suppliers' firms build a strong relationship with their multiple buyers and institutions has to better understand the needs of the firms, to pursue an sequel growth of natural and social environment for the future generations.

As a result, researchers suggest that the locus of implementation of social sustainability initiatives is often situated in buyer-driven knowledge practices on social issues and encouragement programs from institutions.

There is growing interest in social sustainability in buyer-supplier relationships. The findings of this study offer contribution to social sustainability. This paper contributes to the 
increasing body of research on how different barriers influences to implement social sustainability practices by (1) taking a perspective on developing country perspective, and (2) our findings add to understanding to implement social sustainability practices that may potentially help the firm evolve as socially responsible over the time. The findings of this study may provide guidelines to other developing countries like China, India or Brazil to analyze the barriers to social sustainability implementation. This means that international firms sourcing from the developing countries need to support social issues and help suppliers instill sustainability specifically within their manufacturing operations. With respect to policy implications, we suggest that policy incentives on international certification related to health, safety and labour issues are necessary for them to thrive and grow their international business successfully. Besides that, a study has contributed to the social sustainability literature, it has some limitations which provides a baseline for future research on the implementation of social sustainability practices. Future research should incorporate the evaluation of barriers to the implementation of social sustainability practices in the service sector and it may be useful for cross-industry and cross-company comparisons. Thus, in future research studies, academic researchers should include other barriers categories within the domain of social capabilities and technical resources.

\section{References}

Amponsah-Tawiah, K., Ntow, M. A. O., \& Mensah, J. (2015). Occupational Health and Safety Management and Turnover Intention in the Ghanaian Mining Sector. Safety and Health at Work, 7(1), 12-17.

Andersen, M., \& Skjoett-Larsen, T. (2009). Corporate Social Responsibility in Global Supply Chains. Supply Chain Management: An International Journal, 14(2), 75-86.

Andersen, M., \& Skjoett-Larsen, T. (2009). Corporate social responsibility in global supply chains. Supply Chain Management: An International Journal, 14(2), 75-86.

Awan, U. (2019). Effects of buyer-supplier relationship on social performance improvement and innovation performance improvement. International Journal of Applied Management Science, 11(1), 21-35.

Awan, U., Kraslawski, A., \& Huiskonen, J. (2018). Buyer-supplier relationship on social sustainability : Moderation analysis of cultural intelligence. Cogent Business \& Management, 5(1), 1429346.

Baumgartner, R. J. (2009). Organizational culture and leadership: Preconditions for the development of sustainable corporation. Sustainable Development, 17(2), 102-113.

Beske, P., Koplin, J., \& Seuring, S. (2008a). The use of environmental and social standards by German first-tier suppliers of the volkswagen AG. Corporate Social Responsibility and Environmental Management, 15(2), 63-75.

Beske, P., Koplin, J., \& Seuring, S. (2008b). The use of environmental and social standards by German first-tier suppliers of the Volkswagen AG. Corporate social responsibility and environmental management, 15(2), 63-75.

Bhamra, R., Dani, S., \& Burnard, K. (2011). Resilience: the concept, a literature review and future directions. International Journal of Production Research, 49(18), 5375-5393.

Biju, P. L., Shalij, P. R., \& Prabhushankar, G. V. (2017). An evaluation tool for sustainable new product development using analytic hierarchy process approach. International Journal of Innovation and Sustainable Development, 11(4), 393-413.

Bledow, R., Frese, M., Anderson, N., Erez, M., \& Farr, J. (2009). A Dialectic Perspective on Innovation: Conflicting Demands, Multiple Pathways, and Ambidexterity. Industrial and Organizational Psychology, 2(03), 305-337.

Boyd, D. E., Spekman, R. E., Kamauff, J. W., \& Werhane, P. (2007). Corporate social 
responsibility in global supply chains: A procedural justice perspective. Long Range Planning, 40(3), 341-356.

Carter, C. R., \& Rogers, D. S. (2008). A framework of sustainable supply chain management: moving toward new theory. International journal of physical distribution \& logistics management, 38(5), 360-387.

Ciliberti, F., Groot, G. De, Haan, J. De, \& Pontrandolfo, P. (2009). Codes to coordinate supply chains: SMEs' experiences with SA8000. Supply Chain Management: An International Journal, 14(2), 117-127.

Dube, N., Van der Vaart, T., Teunter, R. H., \& Van Wassenhove, L. N. (2016). Host government impact on the logistics performance of international humanitarian organisations. Journal of Operations Management, (July 2015).

Ehrgott, M., Reimann, F., Kaufmann, L., \& Carter, C. R. (2011). Social sustainability in selecting emerging economy suppliers. Journal of business ethics, 98(1), 99-119.

Elkington, J., \& Burke, T. (1987). The green capitalists: Industry's search for environmental excellence. Gollancz.

Gualandris, J., Klassen, R. D., Vachon, S., \& Kalchschmidt, M. (2015). Sustainable evaluation and verification in supply chains: Aligning and leveraging accountability to stakeholders. Journal of Operations Management, 38, 1-13.

Guimarães, L. B. de M., Anzanello, M. J., \& Renner, J. S. (2012). A learning curve-based method to implement multifunctional work teams in the Brazilian footwear sector. Applied Ergonomics, 43(3), 541-547.

Huang, L., Moore, S., \& McCarthy, P. (2014). Managing for business sustainability in China: a case study of Shoetown Footwear Co., Ltd. International Journal of Innovation and Sustainable Development, 8(2), 125-145.

Huq, F. A., Chowdhury, I. N., \& Klassen, R. D. (2016). Social management capabilities of multinational buying firms and their emerging market suppliers: An exploratory study of the clothing industry. Journal of Operations Management, 46.

Husgafvel, R., Pajunen, N., Virtanen, K., Paavola, I.-L., Päällysaho, M., Inkinen, V., Heiskanen, K., Dahl, O., \& Ekroos, A. (2015). Social sustainability performance indicators-experiences from process industry. International Journal of Sustainable Engineering, 8(1), $14-25$.

Hutchins, M. J., \& Sutherland, J. W. (2008). An exploration of measures of social sustainability and their application to supply chain decisions. Journal of Cleaner Production, 16(15), 1688-1698.

ICSU, I. (2015). Review of the sustainable development goals: The science perspective. Paris: International Council for Science (ICSU).

Klassen, R. D., \& Vereecke, A. (2012a). Social issues in supply chains: Capabilities link responsibility, risk (opportunity), and performance. International Journal of Production Economics, 140(1), 103-115.

Klassen, R. D., \& Vereecke, A. (2012b). Social issues in supply chains: Capabilities link responsibility, risk (opportunity), and performance. International Journal of Production Economics, 140(1), 103-115.

Kuppig, V. D., Cook, Y. C., Carter, D. A., Larson, N. J., Williams, R. E., \& Dvorak, B. I. (2016). Implementation of sustainability improvements at the facility level: Motivations and barriers. Journal of Cleaner Production, 139, 1529-1538.

Lim, S. J., \& Phillips, J. (2008). Embedding CSR values: The global footwear industry's evolving governance structure. Journal of Business Ethics, 81(1), 143-156.

Lin, C.-Y., \& Ho, Y.-H. (2008). An empirical study on LSPs' intention to adopt green innovations, 3(1). 
Locke, R. M., Rissing, B. A., \& Pal, T. (2013). Complements or substitutes? Private codes, state regulation and the enforcement of labour standards in global supply chains. British Journal of Industrial Relations, 51(3), 519-552.

Luthra, S., Kumar, V., Kumar, S., \& Haleem, A. (2011). Barriers to implement green supply chain management in automobile industry using interpretive structural modeling technique: An Indian perspective. Journal of Industrial Engineering and Management, 4(2), 231-257. Luthra, S., Mangla, S. K., Xu, L., \& Diabat, A. (2015). Using AHP to evaluate barriers in adopting sustainable consumption and production initiatives in a supply chain. International Journal of Production Economics, 1-8.

Malhotra, M. K., \& Grover, V. (1998). An assessment of survey research in POM: from constructs to theory. Journal of operations management, 16(4), 407-425.

Mamic, I. (2005). Managing global supply chain: the sports footwear, apparel and retail sectors. Journal of business ethics, 59(1-2), 81-100.

Mani, V., Agrawal, R., \& Sharma, V. (2015). Social sustainability in the supply chain: Analysis of enablers. Management Research Review, 38(9), 1016-1042.

Mani, V., Agrawal, R., \& Sharma, V. (2016). Impediments to social sustainability adoption in the supply chain: An ISM and MICMAC analysis in Indian manufacturing industries. Global Journal of Flexible Systems Management, 17(2), 135-156.

Mani, V., Gunasekaran, A., Papadopoulos, T., Hazen, B., \& Dubey, R. (2016). Supply chain social sustainability for developing nations: Evidence from india. Resources, Conservation and Recycling, 111, 42-52.

Merli, R., Preziosi, M., \& Massa, I. (2015). Social values and sustainability: A survey on drivers, barriers and benefits of SA8000 certification in Italian firms. Sustainability (Switzerland), 7(4), 4120-4130.

Popovic, T , Kraslawski, A. (2015). Social Sustainability of Complex Systems. In F. You (Ed.), Sustainability of Products, Processes and Supply Chains: Theory and Applications. Elsevier, 840.

Power, J. D., Mitra, A., Laumann, T. O., Snyder, A. Z., Schlaggar, B. L., \& Petersen, S. E. (2014). Methods to detect, characterize, and remove motion artifact in resting state fMRI. Neuroimage, 84, 320-341.

Saaty, R. W. (1987). The analytic hierarchy process - what it is and how it is used. Mathematical modelling, 9(3), 161-176.

Saaty, T. L. (2008). Decision making with the analytic hierarchy process. International Journal of Services Sciences, 1(1), 83.

Sarkis, J. (2001). Manufacturing's role in corporate environmental sustainability-Concerns for the new millennium. International Journal of Operations $\{\&\}$ Production Management, 21(5/6), 666-686.

Sartor, M., Orzes, G., Di Mauro, C., Ebrahimpour, M., \& Nassimbeni, G. (2016). The SA8000 social certification standard: Literature review and theory-based research agenda. International Journal of Production Economics, 175, 164-181.

Schaarschmidt, M., \& Hoeber, B. (2017). Transforming from service providers to solution providers: implications for provider-customer relationships and customer-induced solution innovation. International Journal of Technology Management, 73(1/2/3), 65.

Schaltegger, S. (2011). 3. Sustainability as a driver for corporate economic success. Society and Economy, 33(1), 15-28.

Severo, E. A., Dorion, E. C. H., \& Guimarães, J. C. F. De. (2017). Innovation and environmental sustainability: analysis in Brazilian metal-mechanic industry. International Journal of Innovation and Sustainable Development, 11(2-3), 230-248.

Siebenhüner, B., \& Arnold, M. (2007). Organizational learning to manage sustainable 
development. Business strategy and the environment, 16(5), 339-353.

Singh, R. K. (2013). Prioritizing the factors for coordinated supply chain using analytic hierarchy process (AHP). Measuring Business Excellence, 17(1), 80-97.

Suopajärvi, L., Poelzer, G. A., Ejdemo, T., Klyuchnikova, E., Korchak, E., \& Nygaard, V. (2016). Social sustainability in northern mining communities: A study of the European North and Northwest Russia. Resources Policy, 47, 61-68.

Terpend, R., \& Krause, D. R. (2015). Competition or Cooperation? Promoting Supplier Performance with Incentives Under Varying Conditions of Dependence. Journal of Supply Chain Management, 51(4), 29-53.

Tseng, S.-C., \& Hung, S.-W. (2014). A strategic decision-making model considering the social costs of carbon dioxide emissions for sustainable supply chain management. Journal of Environmental Management, 133, 315-322.

United Nations. (2015). Transforming our world: the 2030 Agenda for Sustainable Development. New York: United Nations, (1).

van Donk, D., van der Vaart, T., Awaysheh, A., \& Klassen, R. D. (2010). The impact of supply chain structure on the use of supplier socially responsible practices. International Journal of Operations $\{\{\}\{\&\}\{\}\}$ Production Management, 30(12), 1246-1268.

Walker, P. H., Seuring, P. S., Sarkis, P. J., \& Klassen, P. R. (2014). Sustainable operations management: recent trends and future directions. International Journal of Operations $\{\&\}$ Production Management, 34(5).

\section{Biographical note}

Usama Awan is currently a junior researcher in the Industrial Engineering and Management in the School of Business and Management at Lappeenranta University of Technology, Lappeenranta Finland. He has also published papers in peer-reviewed journals, his research profile on Scopus (55849496400) and ORCID (0000-0002-6185-959) Researcher ID (K-5538-2013). His research interests are in the Environmental management practices, Sustainability Management in Supply chain. He has also published journal articles including in International Journal of Environmental Science and Pollution Research, Renewable and Sustainable Energy Reviews and Journal of Cleaner production. Andrzej Kraslawski is a Professor of Systems Engineering at Lappeenranta University of Technology, Finland and Department of Process and Environmental Engineering, Lodz University of Technology, Lodz, Poland. His research interests has been concerned with development and application of methods and tools for knowledge management and especially knowledge discovery, visualization and re-use; sustainability assessment and process safety analysis; disruptive innovations and creativity. Professor Kraslawski has published over 130 research papers in Computer Aided Chemical Engineering Industrial \& Engineering Chemistry Research, Computers \& Chemical Engineering and edited or co-edited over 20 books. Among them a unique book on re-use of design experience in processing industries. Kraslawski was invited to lecture in over 60 universities in Europe, Asia, Africa, North and South Americas.

Janne Huiskonen is a Professor Department of Industrial Management, School of Business and Management, Lappeenranta University of Technology, Finland. His publications appear in a journal such as International Journal of Production Economics, International Journal of Management Practice and International Journal of Services and Operations Management, etc. His research focuses on Service designs, innovation, customer dominant logic and supply chain management. He has also taught logistics courses in other universities: Helsinki University, University of Joensuu, University of Kuopio, and Häme University of Applied Sciences.

Nazia Suleman is an Assistant Professor Depatarmtn of Humanities, COMSATS University Islamabad, Vehari Campus, Pakistan. 